\title{
Prevalensi Otodectes cynotis pada kucing di Klinik Hewan Dunia Satwa Batusangkar, Sumatera Barat
}

\author{
Afifa Ridhoka Waljannah ${ }^{1 *}$, Tetty Barunawati Siagian ${ }^{2}$ \\ ${ }^{1}$ Klinik Hewan Dunia Satwa Batusangkar, Sumatera Barat \\ ${ }^{2}$ Paramedik Veteriner, Sekolah Vokasi Institut Pertanian Bogor, Bogor
}

\begin{abstract}
ABSTRAK: Otodectes cynotis merupakan tungau yang dapat ditemukan di dalam saluran eksternal telinga kucing. Tungau ini menyebabkan kucing menggaruk-garuk telinga, memiringkan telinga dan dapat menyebabkan othematom. Penelitian ini bertujuan untuk menerangkan prevalensi infestasi Otodectes cynotis pada kucing di Klinik Hewan Dunia Satwa Batusangkar. Sumatera Barat Pemeriksaan dan identifikasi tungau Otodectes cynotis pada 20 ekor kucing. Ras kucing yang diperiksa yaitu kucing Domestik, Angora, Himalaya, Persia, dan kucing campuran (mix breed), Pengambilan sampel berupa serumen atau kotoran telinga kucing. Hasil pemeriksaan menunjukkan sebanyak 8 dari 20 (40\%) kucing di Klinik Hewan Dunia Satwa Batusangkar terindentifikasi positif terinfestasi tungau Otodectes cynotis.
\end{abstract}

\section{Kata kunci:}

Otodectes cynotis, ektoparasit, infestasi, kucing, tungau telinga

\section{- PENDAHULUAN}

Prevalensi adalah bagian dari studi epidemiologi yang membawa pengertian jumlah sampel dalam populasi yang mengalami penyakit, gangguan, atau kondisi tertentu pada suatu tempo waktu. Prevalensi tungau Otodectes cynotis yaitu proporsi dari populasi yang memiliki karakteristik dan faktor risiko terdapatnya tungau Otodectes cynotis (Bengi 2017). Tungau Otodectes cynotis merupakan ektoparasit yang hidup didalam saluran telinga eksterna telinga kucing. Tungau ini dapat menginfeksi kucing, anjing, dan karnivora lain seperti rubah dan ferret (Sweatman 1958). Otodectes cynotis dapat menimbulkan gejala klinis jika populasinya meningkat pada inang, serta pada kondisi dan daya tubuh inang yang menurun (Dhingra 2008). Tulisan ini bertujuan untuk menilai prevalensi infestasi Otodectes cynotis pada kucing di Klinik Hewan Dunia Satwa Batusangkar.

\section{- BAHAN DAN METODE}

Pemeriksaan dan identifikasi tungau Otodectes cynotis dilakukan pada 20 ekor kucing. Ras kucing yang diperiksa yaitu kucing Domestik (DSH), Angora, Himalaya, Persia, dan kucing campuran (mix breed). Bahan yang digunakan berupa serumen atau kotoran telinga kucing, larutan $\mathrm{KOH}$ $10 \%$, gelas objek, cover glass, dan mikroskop. Pemeriksaan sampel kotoran telinga menggunakan metode pemeriksaan natif. Pemeriksaan sampel dilakukan di Laboratorium Pusat Kesehatan Hewan Tanah Datar. Prosedur pemeriksaan natif dilakukan dengan meletakan kotoran telinga diatas gelas objek dan diberi satu hingga dua tetes larutan $\mathrm{KOH} \mathrm{10 \% .}$ Pemeriksaan dilakukan dengan menggunakan mikroskop dengan perbesaran $10 x$ dan $40 x$.

\section{- HASIL DAN PEMBAHASAN}

Hasil pemeriksaan menunjukkan adanya infestasi Otodectes cynotis. Berdasarkan hasil pemeriksaan sampel kotoran telinga kucing dan identifikasi ektoparasit didapatkan 8 ekor kucing positif terinfestasi Otodectes cynotis dari 20 sampel kucing yang diamati. Prevalensi infestasi tungau Otodectes cynotis pada kucing di Klinik Hewan Dunia Satwa Batusangkar adalah sebesar $40 \%$.

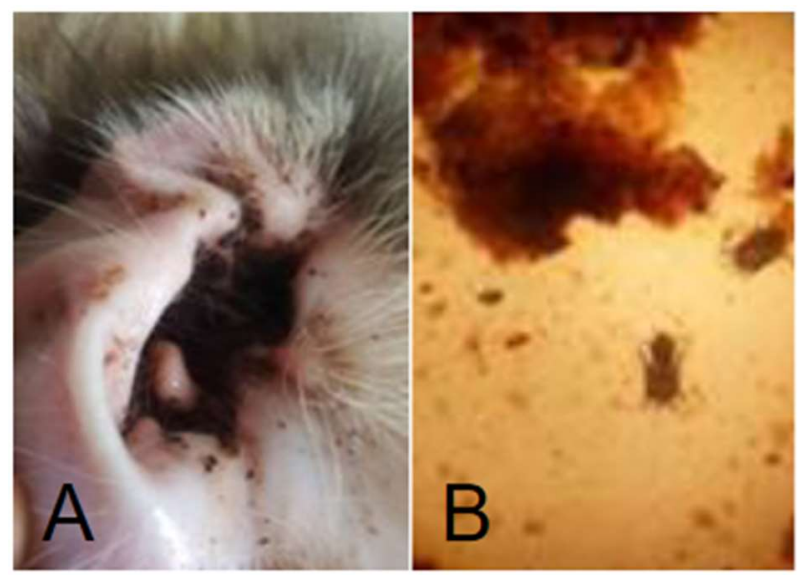

Gambar 1 Kotoran telinga kucing yang akan diambil serumen telinga (A). Otodectes cynotis dari hasil pemeriksaan sampel (B)

Tungau Otodectes cynotis yang banyak terdapat pada telinga kucing diakibatkan oleh suhu dan kelembaban di dalam telinga kucing yang menjadi faktor predisposisi adanya

Diterima: 05-01-2021 | Direvisi: 07-02-2021 | Disetujui: 11-02-2021 (C) 2021 CC-BY-SA. Ini adalah artikel Open Access yang didistribusikan berdasarkan ketentuan dari Creative Commons Attribution ShareAlike 4.0 International License (https://creativecommons.org/licenses/by-sa/4.0/). 
tungau. Faktor lain yaitu kebersihan telinga maupun lingkungan sekitar. Telinga kucing yang jarang dibersihkan dapat menyebabkan tungau mudah menyebar dan berkembang dengan cepat, sehingga tidak dibutuhkan waktu yang lama untuk tungau berproduksi (Akucewich 2008). Infestasi tungau ini pada kucing menyebabkan pruritus, hewan sering menggaruk bagian tubuh yang gatal, serumen telinga berwarna gelap dan dalam infestasi yang tinggi dapat menyebabkan otitis (Bowman et al. 2002).

Tabel 1 Hasil pengamatan kotoran telinga kucing

\begin{tabular}{|c|c|c|c|}
\hline No & Nama Kucing & Infeksi & Jenis Tungau \\
\hline 1 & Ciko & + & Otodectes cynotis \\
\hline 2 & Cimot & + & Otodectes cynotis \\
\hline 3 & Meo & + & Otodectes cynotis \\
\hline 4 & Apung & + & Otodectes cynotis \\
\hline 5 & Panda & + & Otodectes cynotis \\
\hline 6 & Kitty & + & Otodectes cynotis \\
\hline 7 & Unyil & + & Otodectes cynotis \\
\hline 8 & Jimmi & + & Otodectes cynotis \\
\hline 9 & Amy & - & - \\
\hline 10 & Bella & - & - \\
\hline 11 & Alexa & - & - \\
\hline 12 & Coco & - & - \\
\hline 13 & Meow & - & - \\
\hline 14 & Kiko & - & - \\
\hline 15 & Kimmy & - & - \\
\hline 16 & Leo & - & - \\
\hline 17 & Jojo & - & - \\
\hline 18 & Cici & - & - \\
\hline 19 & Aming & - & - \\
\hline 20 & Niko & - & - \\
\hline \multicolumn{2}{|c|}{ Prevalensi } & \multicolumn{2}{|c|}{$8 / 20(40 \%)$} \\
\hline
\end{tabular}

\section{SIMPULAN}

Kucing di Klinik Hewan Dunia Satwa Batusangkar memiliki prevalensi infestasi Otodectes cynotis sebesar $40 \%$.

\section{INFORMASI PENULIS}

\section{Penulis Korespondensi}

*ARW: afifaridhokawaljannah@gmail.com

Mahasiswa Paramedik Veteriner, Sekolah Vokasi, Institut Pertanian Bogor.

\section{- PUSTAKA ACUAN}

Akucewich. 2002. Prevalence of ectoparasites in a population of $b$ feral cats from north central Florida during the summer. Veterinary Parasitology. 109 (1-2): 129-139.

Bengi WTM. 2017. Isolasi dan identifikasi Pseudomonas aeruginosa pada Kasus Ear mites kucing domestik (Felis domesticus) di Kecamatan Syiah Kuala Banda Aceh. Jurnal Ilmiah Mahasiswa Veteriner. 1(2): 161-168

Bowman DD.2002. Feline Clicical Parasitology. Iowa State University Press. Iowa.

Dhingra PL.2008.Perbandingan Efektifitas Ofloksasin Topikal dengan Ofloksasin Kombinasi Steroid Topikal pada Otitis Eksterna Profunda di Makassar. Skripsi. Universitas Hasanudin.

Nurulhuda W. 2017. A survey of ear mites (Otodectes cynotis) in stray cats in kota Bharu, Kelantan, West Malaysia. Malaysian Journal of Veterinary Research. 8(1): 173-176.

Sweatman GK. 1958. Biology of Otodectes Cynotis, The Ear Canker Mite of Carnivores. Canadian Journal of Zoology.36: 849-862. 